\section{Reforestation for environmental services as valued by local communities: a case study from Lebanon}

Reforestation for environmental services

\author{
Juliette Amidi \\ American University of Beirut, Beirut, Lebanon \\ Jean Mikhael Stephan \\ L2GE, Life and Earth Sciences, Lebanese University, Fanar, Lebanon, and \\ Elias Maatouk \\ L2GE, Lebanese University, Beirut, Lebanon
}

Received 16 July 2019 Revised 28 January 2020 Accepted 17 October 2020

\begin{abstract}
Purpose - Lebanon has been subject to important reforestation activities which resulted in the establishment of several cedars, pine and other mixed forest stands on communal lands. These stands are not designated for timber production but rather for nonwood forest products (NWFPs), landscape restoration and for environmental services. The study aims at valuating old reforested sites from the perspective of rural communities neighboring those reforested stands.

Design/methodology/approach - To assess the non-timber goods and services provided by these forest ecosystems, 13 reforested sites located in different regions in Lebanon were selected. The socioeconomic assessment was done using questionnaires distributed to locals that have close interactions with the neighboring forests; it included, among others, a double-bonded dichotomous contingent valuation (CV) related to their willingness to pay (WTP) for reforestation and forest management activities.

Findings - Results of the goods and services assessment revealed that the forests have multifunctional uses with ecotourism as a major activity in all forest types. The $\mathrm{CV}$ showed that $75 \%$ of respondents did express a WTP. Most of the respondents did so, thus giving a great importance to intrinsic values of the forests. Lower income did not negatively affect the WTP of respondents but rather age and the educational level did. Other factors such as forest type, forest surface and the biodiversity status of the sites did not have an impact on WTP.

Practical implications - These results are very informative for governmental policies seeking funds to perform reforestation programs for environmental objectives, involving local communities in co-funding these programs would help insure the sustainable conservation of reforestation sites.

Social implications - Despite their relative low income, poor communities are willing to pay to sustain forests and their ecosystem services.

Originality/value - It is the first time that a $\mathrm{CV}$ is used for ecosystem services regenerated from 50-60 years old reforested sites in a semiarid region, where trees are not planted for timber production. It is one of the few
\end{abstract}

(C) Juliette Amidi, Jean Mikhael Stephan and Elias Maatouk. Published in Forestry Economics Review. Published by Emerald Publishing Limited. This article is published under the Creative Commons Attribution (CCBY 4.0) licence. Anyone may reproduce, distribute, translate and create derivative works of this article (for both commercial and non-commercial purposes), subject to full attribution to the original publication and authors. The full terms of this licence may be seen at http://creativecommons. org/licences/by/4.0/legalcode

This work was supported by the Association for Forests, Development and Conservation (AFDC) through assistance in the field survey and in the selection of the forested sites. The work was realized as a thesis at the Lebanese University Master Program entitled "Biodiversity, Management and Conservation of Natural Resources." This research did not receive any specific grant from funding agencies in the public, commercial or not-for-profit sectors.

Declarations of interest: none 
FER

2,1 examples were lower income did not affect the WTP for forests providing environmental services on communal lands.

Keywords Reforestation, Socioeconomic assessment, Contingent valuation, Willingness to pay, Goods and services

Paper type Case study

\section{Introduction}

Lebanon is a small country in the eastern Mediterranean Basin. Forests have been historically supplying timber from its prominent coniferous trees to past civilizations of the Near East. However, the dependency of people on these resources led to the degradation of once extensively distributed forests. Reforestation programs were initiated at the starting of the 1960s under the "Green plan," while timber production from conifer species was prohibited by law since 1996. Reforestation initiatives were carried out on communal lands, which were owned by village communities and managed by their respective municipalities. The purpose was to increase the total forested area to over $30 \%$ of the Lebanese territory through the establishment of mixed stands including conifer and hardwood trees (Talhouk et al., 2001). Some of these sites are currently part of protected areas such as the Shouf Biosphere Reserve (SBR), while others are neglected. Forests in Lebanon cover around $13.4 \%$ of the country (FRA, 2005, 2010, 2015). Since the government has to address other priorities than reforestation, these initiatives are highly dependent on external financial resources from different donors and from the private sector. As the current legal framework prohibits timber exploitation, private landowners are reluctant to invest in tree plantations (Sarkissian et al., 2017). Yet, Mediterranean forests are known to provide public goods and externalities such as watershed and soil protection, landscape and aesthetic services, climate and carbon regulation and non-timber forest products (Croitoru, 2007; Palahi et al., 2008). However, in Lebanon, these were only ranked according to their importance (goods separated from services), but no economic value was estimated except for major products like pine nuts and charcoal (FRA 2005, 2010 and 2015) or by estimating the total economic value (TEV) in the SBR and the Jabal Moussa Biosphere Reserve (JMBR) (El- Jisr et al., 2015; Karam, 2016).

Another investigation used mixed methods in a survey with landowners with three option choices: results-based loan, action-based grant and results-based payments. Qualitative examining revealed economic, social and legal repercussions that limited willingness to participate in the results-based contract option for planting forest trees on private land (Sarkissian et al., 2017). These studies showed that it is pertinent to know if local communities valuate forest goods and services as a key step to understand if they are willing to mobilize their resources to sustain those reforestation initiatives on communal lands.

The basis of the economic valuation of ecosystems is the study of both goods and services provided by these ecosystems to society. The concept of TEV includes the sum of all the values of the goods and services provided by the ecosystem. In the absence of direct and indirect prices, hypothetical markets are created in order to get these values (Pascual et al., 2010). The TEV takes into account both use and nonuse values of ecosystems (Boman $e$ t al., 2001; Hein et al., 2006). With the presence of nonuse values, stated preference approach is needed. Stated preference methods use hypothetical changes to simulate market and demands and changes in ecosystem services. The use of stated preference approach allows in reflecting more scenario variations, compared to real-world situations (Adamowicz et al., 1998). Among the main types included in the stated preference methods is the contingent valuation (CV) method. CV consists in administering a questionnaire to people in order to know the willingness to pay (WTP) for an improvement in an ecosystem service or the willingness to accept (WTA) the loss of this ecosystem service (Pascual et al., 2010). 
Theoretically, the WTP and WTA should be similar; however, studies have shown that for similar ecosystem services, the WTA exceeds the WTP (Vatn and Bromley, 1994). CV provides results that are directly dependent on the hypothetical markets assumed for the suggested service (Mavsar et al., 2014). Thus, CV can be used when market information is missing and is widely adopted in economic valuation of environmental goods (Georgiou et al., 1997). According to Haab and McConnel (2002), the dichotomous or discreet CV is a format where the respondents are asked simple "yes" or "no" questions. Generally, the doublebounded dichotomous format is preferred since it avoids many biases that can occur in the CV method (Belete and Assefa, 2003). Moreover, the dichotomous choice format is used because it reduces cognitive burden on respondents since it uses real-life decision-making prices and can have high incentive compatibilities depending on the circumstances (Carson et al., 2000). WTP has been applied for a wide array of environmental studies such as the payment for environmental public goods (Baumgärtner et al., 2017), the behavior of forest landowners to embed voluntary forest conservation actions in their forest management plans (Rabotyagov and Lin, 2013) and payment for environmental conservation (Han et al., 2011). In the Eastern Mediterranean region, WTP enabled the valuation of the impact of climate change on rangeland ecosystems (Fleischer and Sternberg, 2006). Nonetheless, these investigations target either landowners or citizens of big urban areas.

The aim of this study is to assess the goods and services provided by old reforested sites and to value their socioeconomic and environmental importance. This would help to assess the long-term socioeconomic value and cost-efficiency of reforestation plans and the possibility to autofinance these activities through the contribution of local communities. The results would also allow assessing the stewardship of neighboring communities for such initiatives. Hence, this investigation answers two questions:

$R Q 1$. What are the main goods and services provided by old reforested sites as perceived by the neighboring communities?

$R Q 2$. Are the local communities willing to pay for the conservation and management of these sites to sustain those services?

\section{Material and methods}

\subsection{The study area}

A total of 13 reforested sites that were part of old reforestation activities that took place under the Green Plan were selected. The sites were distributed over different villages in different administrative districts as shown in Figure 1. Site selection took into consideration the following criteria: forest type and species composition, forest ownership, protection status and forest bioclimatic zones. Selected sites were representative of the diversity of these criteria along the country. Further, two sites included cedar forests (Cedrus libani), four sites included stone pine forests (Pinus pinea) and the remaining seven sites were mixed forests combining several types of native (Cedrus libani, Pinus pinea, Pinus brutia, Cupressus sempervirens, Quercus calliprinos and Quercus infectoria) and non-native species (Cupressus arizonica, Pinus canariensis, Robinia pseudoacacia, etc.)

The sites had different surface areas and were selected based on different altitudes and bioclimatic zones. Appendix 1 summarizes the geographic coordinates of each site including its area and the type of forest. All the selected sites are found on communal lands (owned by all the village population) except one pine site in Jisr Al Qadi village, that is, the property of a religious community. One site (Barouk) is within a United Nations Educational, Scientific and Cultural Organization (UNESCO) biosphere reserve, while other conifers are protected and not exploited for timber, while stone pine is generally exploited for pine nut production. 


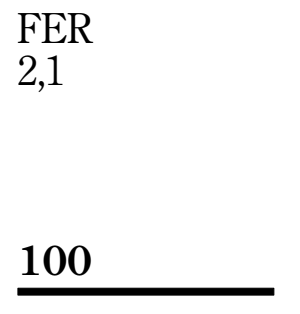

Figure 1.

Locations of the selected reforested sites

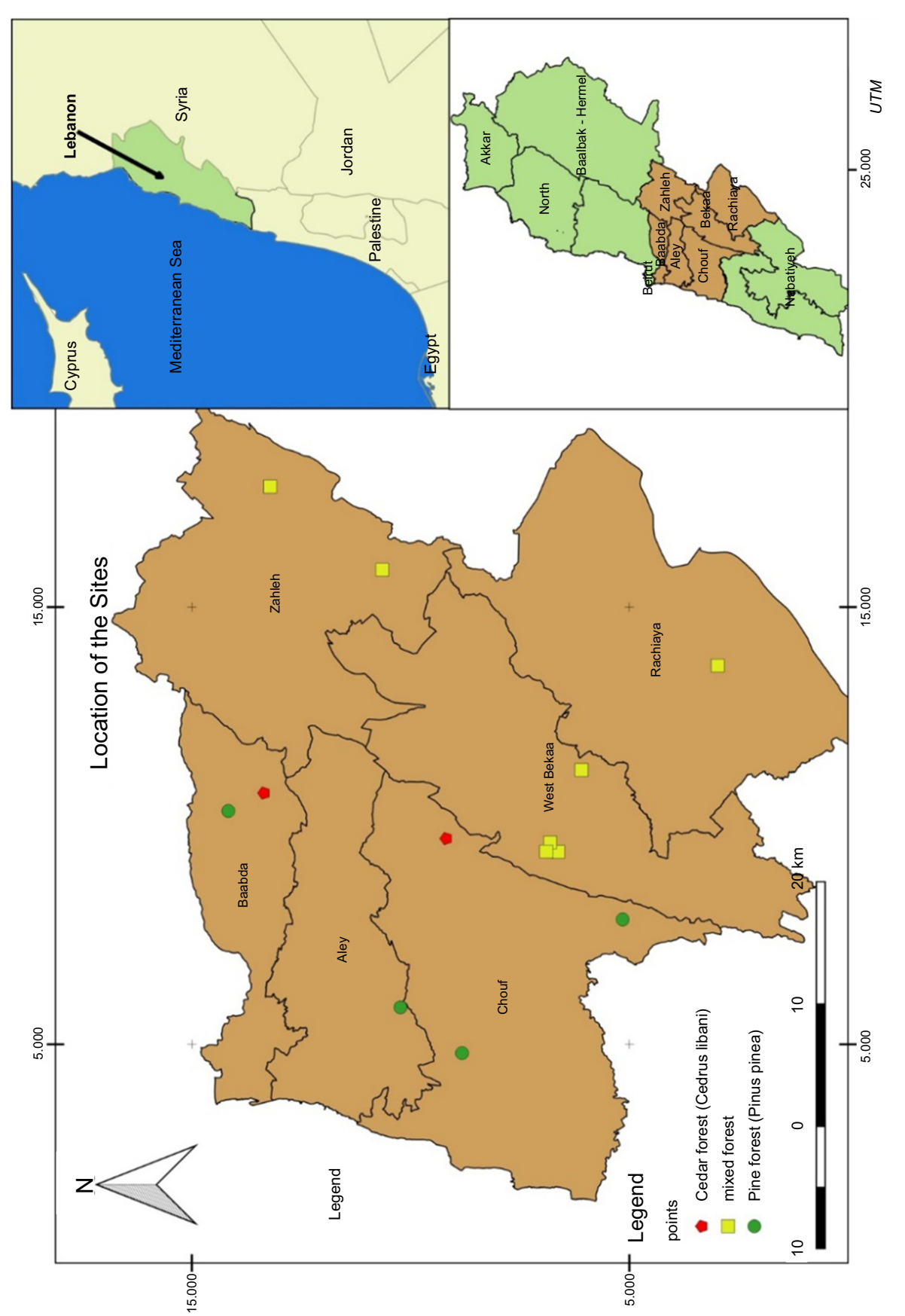




\subsection{Data collection}

A questionnaire was developed and distributed to 253 respondents in 13 villages surrounding the reforested sites (see full questionnaire in Appendix 2). Surveys were filled to the extent possible with beekeepers, shepherds, hunters, plant collectors and guides to ensure that direct beneficiaries from the forest are included. Forest guards and local authorities were approached as well in order to validate managerial activities and get general information about the forest. In addition, respondents' panel included a wide category of people having different types of occupations that would be the larger public potentially benefiting from the forests. Hence, all respondents were adults and randomly distributed between genders. The survey was conducted between May and July of 2017.

The questionnaire objectives were (1) the assessment of the goods and services and the socioeconomic value of reforested sites through the identification of the main activities undertaken in the forests, followed by a valuation scenario in order to understand the importance value of the forests (Mavsar et al., 2014). (2) The estimation of the peoples' WTP for the conservation and management of the reforested sites and their expansion through further reforestation activities using the $\mathrm{CV}$ method was used to estimate the economic value of nonmarket goods or hypothetical markets in which people were asked to state monetary bids for this good (Hanemann et al., 1991; Venkatachalam, 2003).

The detailed survey included combined general information about goods and services with a WTP question. The questionnaire also consisted of a multiple answer format and a double-bounded dichotomous choice WTP format (Belete and Assefa, 2003). General knowledge about the goods and services provided by the forests, socioeconomic and demographic information was collected from the respondents, in addition to the WTP question regarding the implementation of a management plan and the increase of the forest area that was proposed to the respondents.

The WTP section included (Belete and Assefa, 2003):

(1) The stated scenario is a hypothetical description of the change that will occur in the good or the service or the program that will be implemented. It should be designed in a way that respondents are able to understand the context of the scenario (Johnston et al., 2017). While conducting the surveys, the valuation scenario was stated directly to the respondents. First, the baseline was described to the respondents mentioning the reforestation efforts in the 1960s, followed by the conditions under which the change will occur; in this study, the scenario included implementing a management plan in collaboration with the local communities for the already established old reforested sites to reduce the risks of reverse degradation, improve the landscape and increase the production of goods and services. The scenario also stated the possibility of expansion of these sites through the implementation of future reforestation activities, with a payment vehicle through the local authority (i.e. municipality, biosphere reserve management team or the religious committee).

(2) A double-bounded dichotomous form was used in this study as shown in Figure 2. In our case, first the respondent was asked if he/she has a WTP to implement the program. When the answer was "yes," a double-bounded dichotomous form was used, where the individual was asked if he/she would be willing to pay the stated amount of 30,000 LBP (equivalent to 20 USD during the survey period [1]); if he/she answered "yes," the amount was doubled to 60,000 LBP; if he/she answered "no," the amount was reduced to 15,000 LBP. The amount of bids for the WTP is based on the TEV per hectare of the SBR and the JMBR and the number of inhabitants around these reserves that are benefiting from their services (i.e. around ten persons per hectare) (El Jisr et al., 2015; Karam, 2016).
Reforestation for environmental services 
FER

2,1

\section{2}

(3) The WTP question was followed by the understanding and certainty questions in order to comprehend the reasons behind expressing or not expressing a WTP.

Finally, socioeconomic and demographic information was collected regarding the age classes (20-40, 40-60 and above 60 years old), gender, education level (primary/secondary, technical and university), type of residency (permanent or summer resident) and income ranges $(<1 \mathrm{M}$, 1M-2M, 2M-3M, 3M-4M and >4M LBP).

\subsection{The data analysis}

The CV method was used to estimate all uses of the selected sites including direct and indirect services and nonuse values such as bequest and existence values.

The data were analyzed using XL-STAT statistical analysis software. Multiple answer questions were analyzed using multiple responses since respondents were allowed to tick all the options that applied to the question.

WTP was analyzed using bar charts, according to several factors including socioeconomic, potential biodiversity and surface area of the selected forests, forest type, etc. We used correlation and the principal component analysis to depict what factors affect the most the WTP.

\section{Results and discussion}

In total, 253 people were interviewed, in which $66 \%$ were men and $34 \%$ were women. Of the respondents, 63 and $10 \%$ have attended primary and technical schools, respectively, and only $27 \%$ have reached university level in their studies. Regarding the distribution of the respondents' income ranges, only $7 \%$ earn more than $3 \mathrm{MLPB}$, while the majority get monthly wages below $1 \mathrm{M}$ LBP. For more information about the socioeconomic features of respondents, please refer to Appendix 3. Figure 3 shows the importance value that locals attribute to the mostly cited forests including landscape/aesthetic and touristic/recreational services (respectively, 82 and $75 \%$ of the answers), even though not all selected reforested sites provide ecotourism services at the same level of importance. This confirms people's recognition for the added value of a forest landscape (Sattout et al., 2007). Roughly half of the respondents considered that the reforested sites have an intrinsic biodiversity value and that the loss of such ecosystems would have negative repercussion on biodiversity. They also reckoned the role of forested sites in regulating and supporting services like erosion control and climate/flood regulation. Ecotourism was the only income-generating activity that was mostly cited since these forests were not dedicated initially for the exploitation of wood and nonwood forest products (NWFPs) (except for pine nuts). It was also clear that goods (fuel wood and nonwood products) are less important in reforested sites. These activities are either prohibited (like timber exploitation and wood cutting) or accessible to a limited number of beneficiaries (i.e. NWFPs).

Figure 4 illustrates the goods and services provided by the different types of forests selected for this study as seen by respondents. The chart revealed important variations between the goods and services provided by the selected forests. Ecotourism remains the major service in all forest types, mostly in cedar and mixed forests. Cedar forests seemed to provide important ecotourism services which is in line with the TEV that was calculated for

Figure 2.

Double-bounded dichotomous form used for contingent valuation

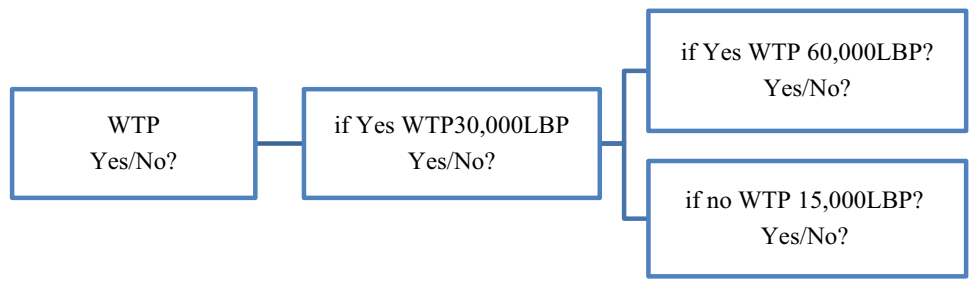




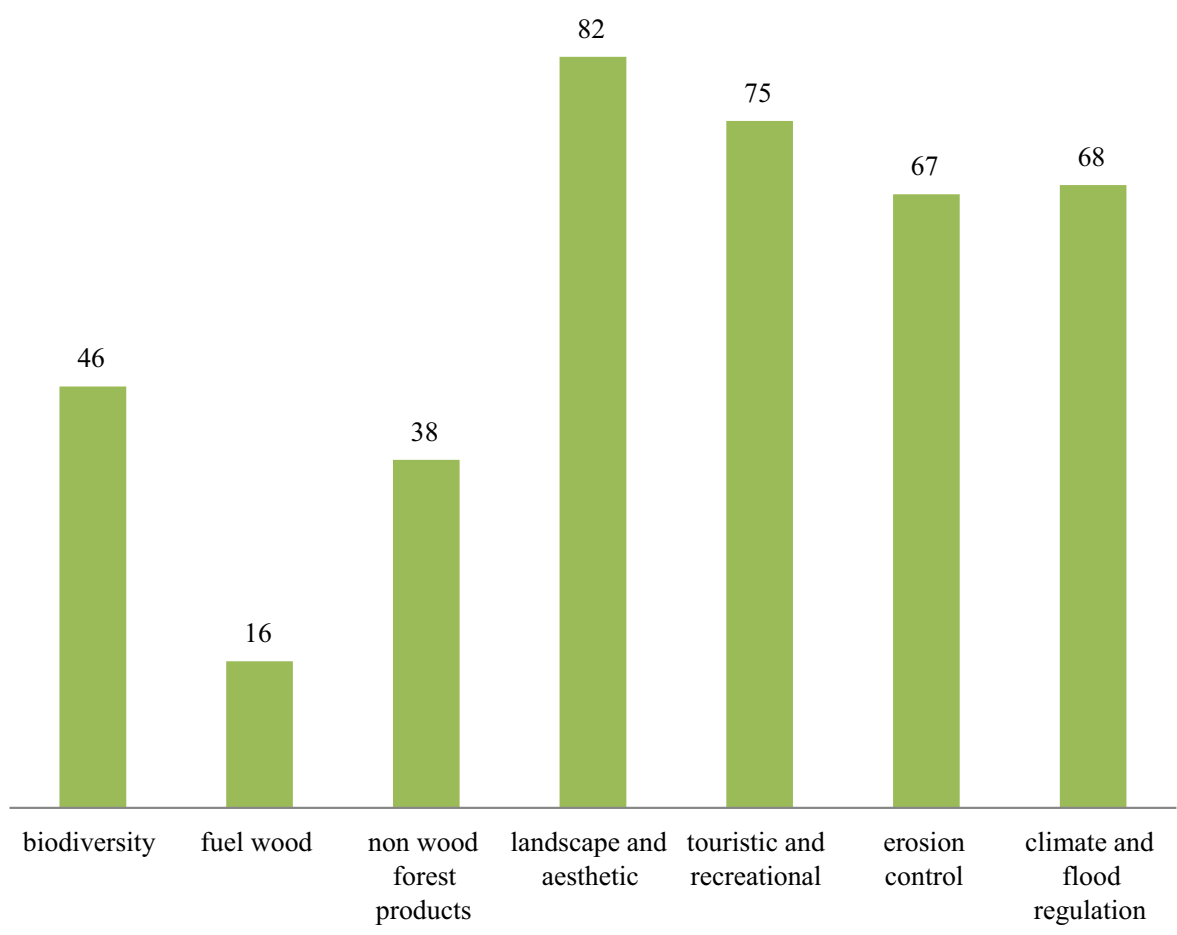

Reforestation

environmental services

103

Figure 3.

Reforested sites' goods and services importance values as seen by respondents (in

$\%$ of responses with multiple choices)

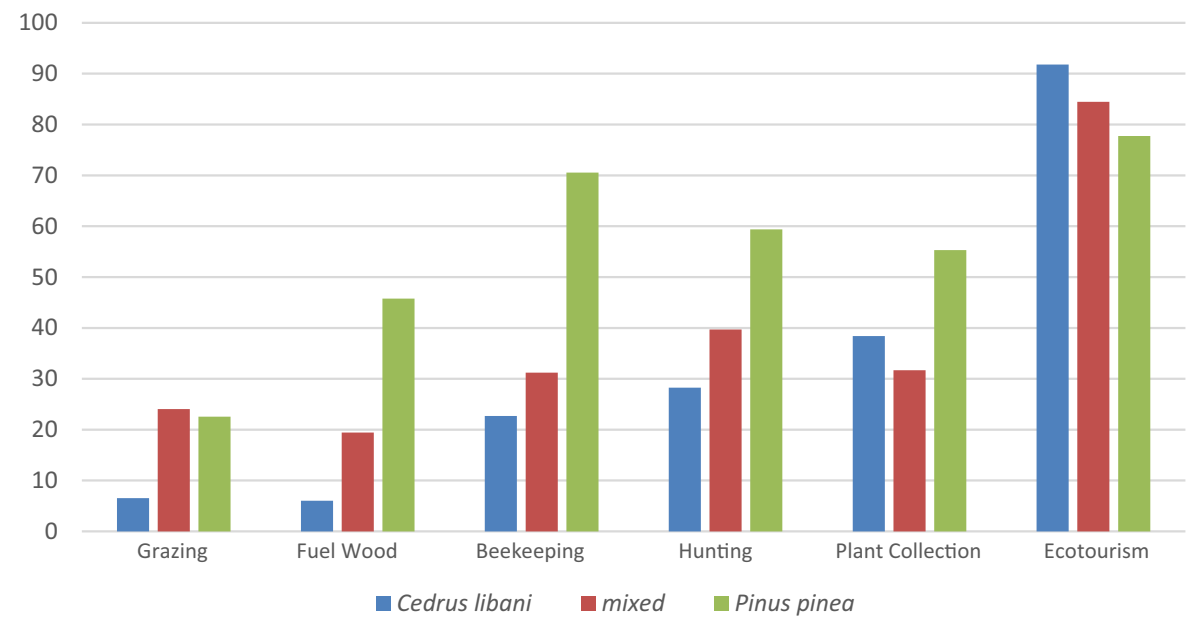

Figure 4.

Goods and services provided by each forest type sites as seen by respondents (in \% of responses with multiple choices)

the SBR that includes the largest cedar forest in Lebanon (E1 Jisr et al., 2015). Grazing and the removal of fuel wood are particularly low in cedar forests since these are mostly in protected areas. Stone pine forests exhibit a multiple functionality with significant provision of other goods and services in comparison to other forest types, while mixed forests have intermediate values in general. The diversity of goods and services provided is attributed to the high 
FER

2,1

\section{4}

biodiversity and the multifunctionality of Mediterranean forests (Palahi et al., 2008). These findings confirm that when it comes to insuring the sustainability of the goods and services provided, it is important to take into consideration biodiversity in the management of these forests (Larrieu and Gonin, 2016).

Figure 5 shows that $75 \%$ of the interviewees are willing to pay for forest management to sustain ecosystem services, where $45 \%$ of the respondents stated amount of 30,000LBP and $29 \%$ of the respondents doubled the stated amount. Only 25\% did not express a WTP and rejected both bids. Reasons behind the WTP varied a bequest and nonuse value (right of forests to exist $74 \%$ and conservation for future generation $73 \%$ ), direct use values (36\%) and indirect use values $(56 \%)$ as illustrated in Figure 6a. Causes of nonexpression of a WTP were mostly the economic situation of the respondent (54\%) and the lack of transparency of the implementing bodies $(31 \%)$ as shown in Figure $6 \mathrm{~b}$.

In the second step, we analyzed factors affecting the WTP. PCA results did not show any significant factor driving the WTP of respondents (Appendix 4). The forest type did not significantly affect the WTP among respondents, although variation existed among forest types ( $81 \%$ for cedar, $75 \%$ for mixed and $70 \%$ for pine forests) as shown in Figure 7a. Fewer people were willing to pay for pine forests, confirming that WTP is not exclusively linked to the type and number of services provided by these forests. Pine nuts extraction in communal lands is leased by the municipalities on a yearly basis, with one-third of the amount of the revenues used in a revolving fund for reforestation activities. This would explain the reluctance of the respondents to have a WTP as they consider that there is enough fund to sustain the forest management. WTP was expressed in other mixed conifer forest stands; in some areas, there is a certain concern toward the presence of the forest and that WTP is not only linked to the types of services provided by these forests but also to their landscape, intrinsic and regulatory values, legal protection of conifers and land ownership. This gives an important indication on the level of concern that people express toward these forests, regardless of their type.

WTP decreased with age, and significantly after 60 years (Figure $7 \mathrm{~b}$ ), which is attributed to the fact that elderly people are not income generating and have other priorities for their retirement. Regarding gender, there were no major differences witnessed between male and

Figure 5.

Percentage of responses for the stated willingness to pay (in LBP)

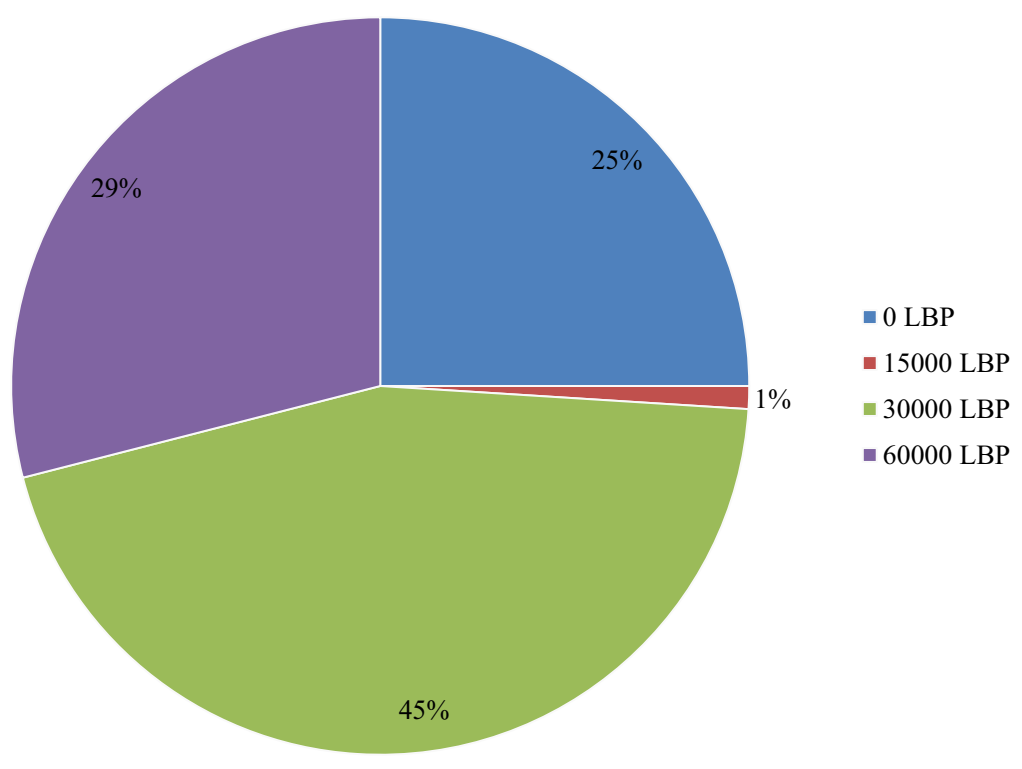




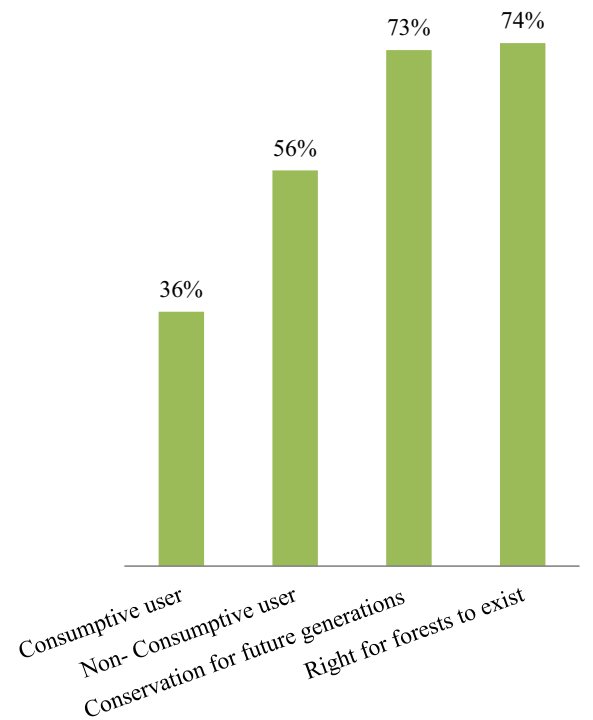

(a)

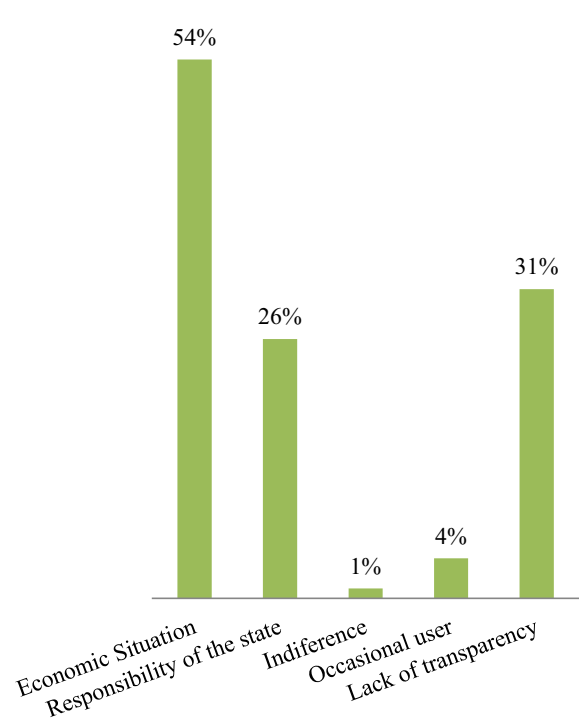

(b)

\section{Reforestation \\ environmental services}

105

female respondents, knowing that male respondents were the majority of interviewees (Figure 7c). The education level did not significantly affect the WTP, yet respondents holding a university diploma expressed a higher WTP (Figure 7d), converging with the findings of other authors (Xiong et al., 2018; Zheng and Tu, 2009). Despite their low income (less than $1 \mathrm{M}$ $\mathrm{LBP} /$ month), $67 \%$ of the respondents having low income expressed WTP. The highest WTP percentage was observed among the middle-income category (income between 1 and $2 \mathrm{M}$ $\mathrm{LBP} /$ month) as illustrated in Figure 7e.

Finally, when WTP was compared by both forest type and income, results revealed that most respondents with lower and middle income are willing to pay for all three types of forests, though mixed forests have the highest percentage (approximately 35\%). It is noteworthy to highlight that very few respondents having higher income (more than $4 \mathrm{M} \mathrm{LBP}$ ) were near the selected forest sites and none near cedar forests (Figure 7f). In addition to the previous results, a correlation analysis showed that surface area of the studied forest stands and the potential biodiversity indices were not correlated with the WTP (results not shown here).

There is a high WTP among the respondents and their economic situation is not affecting their WTP for the proposed project. Even respondents with lower incomes are willing to pay for the management and increase of the forest area. Yet the economic situation is the main cause for non-willingness to pay. These results are divergent from the general trend (Baumgärtner et al., 2017; Zheng and Tu, 2009; Xiong et al., 2018) but show a nonlinear relationship with income as confirmed by Barbier et al. (2017). The WTP could indicate that rural communities still rely on forests and consider the presence of these forests as a need for their livelihood (Sharaunga et al., 2015).

This reveals out the importance of supporting these communities through reforestation and forest management as well as through the implementation of awareness campaigns in order to increase the goods and services provided by the forests, while insuring at the same time, the conservation and sustainability of these forests (Sattout et al., 2007).

If we consider the reforestation of tha in each village by planting 600 seedlings per ha for the price of $10,000 \mathrm{LBP}$ per seedling, then this would require the participation of 200 persons per village to pay the minimum amount of $30,000 \mathrm{LBP}$ each, which is equivalent to a total of 


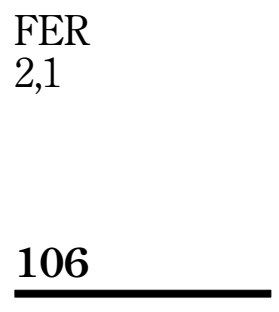

Figure 7.

Willingness to pay by forest type: (a) factor affecting the

willingness to pay as selected by respondents:

willingness to pay by age; (b) willingness to pay by gender; (c) willingness to pay by education level; (d) willingness to pay by income; (e) willingness to pay by forest type; (f) income

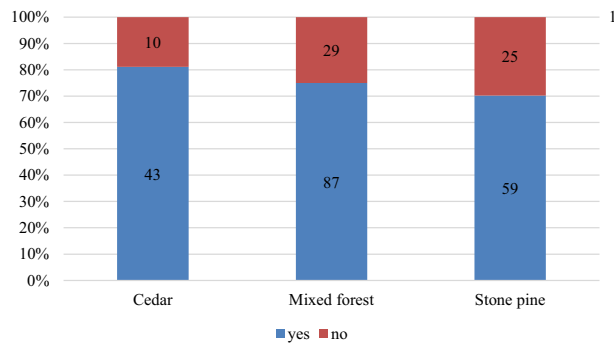

(a)

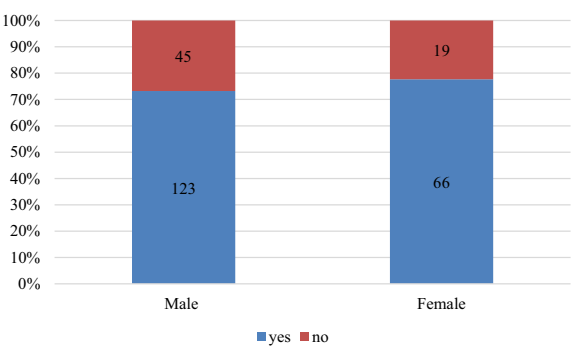

(c)

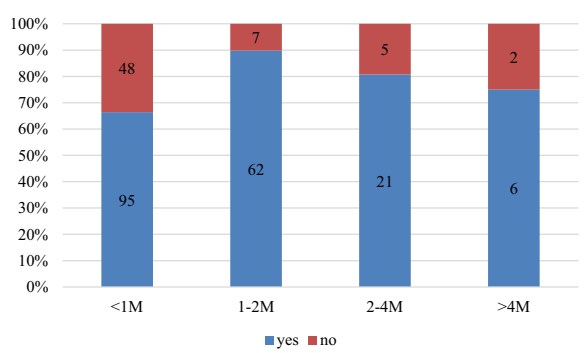

(e)

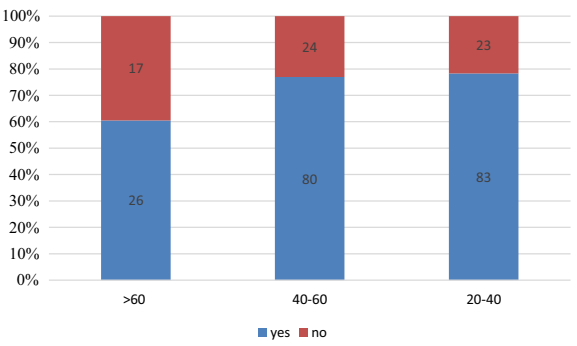

(b)

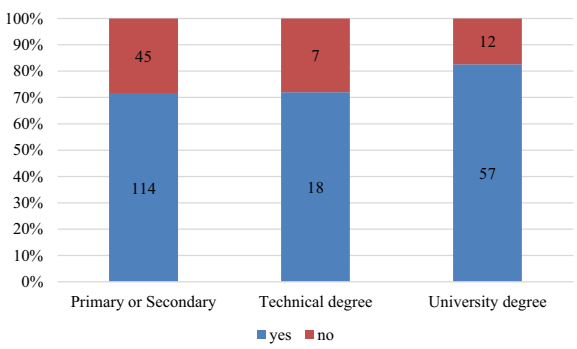

(d)

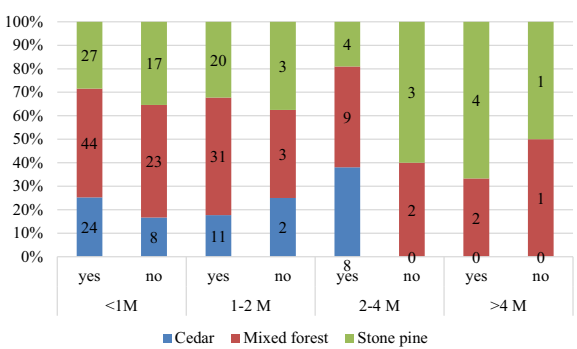

(f)

6,000,000LBP. From another perspective, 650,000 LBP/ha are required to manage those old reforested sites and the expected TEV would be between five and 19 folds that amount based on the approaches used in the two studies of the biosphere reserves. As a result, the expected TEV would vary between 3.25 M LBP and $12.35 \mathrm{MLBP} / \mathrm{h}$ in terms of return from goods and services in addition to the direct value of pine forests and which should be added to the TEV.

\section{Conclusion}

This study conducted a socioeconomic assessment for the first time in Lebanon on selected reforested sites that were part of old reforestation activities that are not dedicated for timber production. The socioeconomic assessment was based on surveys conducted with locals, mostly including people that benefit directly from these forests. Pine forests seemed to provide more direct services than the other ecosystems did, while the cedar forest presented important culturalservices.

Lower income did not affect people's WTP for the management communal forests as rural communities are more dependent on the services provided by the forest and consider the 
presence of the latter as a need for their livelihood. Communities are willing to pay if reforestation activities on communal lands are of a recreational or environmental interest (soil and water conservation, carbon sequestration, aesthetic value, etc.) and are relatively reluctant if a direct economic good is exploited by the managers (i.e. pine production). Governance and transparency in management plans are key factors to improve the WTP. Yet the dramatic economical crisis is also a key barrier for WTP. Sustaining the livelihood of rural communities is a must, while managing forested sites should foresee more income generating services.

Finally, future work should investigate the degree of dependency of rural communities on these reforested sites and target city dwellers in order to reveal their willingness to fund reforestation policies with environmental objectives.

\section{Note}

1. Lebanon faces a sharp devaluation of its currency towards the USD since October 2019. By end of 2020, 30,000 LBP are equivalent to 5 USD.

\section{References}

Adamowicz, W., Boxall, P., Williams, M. and Louviere, J. (1998), "Stated preference approaches for measuring passive use values: choice experiments and contingent valuation", American Journal of Agricultural Economics, Vol. 80 No. 1, pp. 64-75.

Barbier, E.B., Czajkowski, M. and Hanley, N. (2017), "Is the income elasticity of the willingness to pay for pollution control constant?", Environmental and Resource Econonomics, Vol. 68, pp. 663-682.

Baumgärtner, S., DruppMeya, M.J., Munz, J. and Qaas, M. (2017), "Income inequality and willingness to pay for environmental public goods", Journal of Environmental Economics and Management, Vol. 85, pp. 35-61.

Belete, Z. and Assefa, Y. (2003), "Willingness-to-pay for protecting endangered environments: the case of Nechsar National Park", Organization for Social Science Research in Eastern and Southern Africa (OSSREA), Vol. 31, p. 29.

Boman, M., Kriström, B. and Kengen, S. (2001), "Valuing the multiple functions of forests", World Forests, Markets and Policies, pp. 149-161.

Carson, R.T. and Grooves, T. (2000), "Incentive and informational properties of preference questions", Paper Presented at Kobe Conference on Theory and Application of Environmental Valuation, Kobe, Japan.

Croitoru, L. (2007), "How much are mediterranean forests worth?", Forest Policy and Economics, Vol. 9 No. 5, pp. 536-545.

El Jisr, K., Abou Rayan, O. and Chabarekh, C. (2015), Shouf Biosphere Reserve: The Economic Value (Rep.), available at: https:/portals.iucn.org/library/sites/library/files/documents/Rep-2015-009. pdf (accessed 29 May 2017).

Fleischer, A. and Sternberg, M. (2006), "The economic impact of global climate change on Mediterranean rangeland ecosystems: a space-for-time approach”, Ecological Economics, Vol. 59, pp. 287-295.

Forest Report Assessment (FRA) (2005, 2010, 2015), "Food and agriculture organization of the united nations (UNFAO)", available at: http://www.fao.org/forestry/15565-0f921641e230ef06f11d15b8856f2ff07.pdf http://www.fao.org/3/a1549E/al549E.pdf - http:/www.fao.org/3/a-az257e.pdf.

Georgiou, S., Whittington, D., Pearce, D. and Moran, D. (1997), Economic Values and the Environment in the Developing World, Edward Elgar Publishing, Cheltenham.

Haab, T.C. and McConnell, K.E. (2002), Valuing Environmental and Natural Resources: The Econometrics of Non-Market Valuation, Edward Elgar Publishing, Cheltenham.

Han, F., Yang, Z., Wang, H. and Xu, X. (2011), "Estimating willingness to pay for environment conservation: a contingent valuation study of kanas nature reserve, Xinjiang, China", Environmental Monitoring and Assessment, Vol. 180, pp. 451-459.
Reforestation for environmental services 
FER

2,1

Hanemann, W.M., Loomis, J. and Kanninen, B. (1991), "Statistical efficiency of double bounded dichotomous choice contingent valuation”, American Journal of Agricultural Economics, Vol. 73 No. 4, pp. 1255-1263.

Hein, L., Van Koppen, K., De Groot, R.S. and Van Ierland, E.C. (2006), "Spatial scales, stakeholders and the valuation of ecosystem services", Ecological Economics, Vol. 57 No. 2, pp. 209-228.

Johnston, R.J., Boyle, K.J., Adamowicz, W., Bennett, J., Brouwer, R., Cameron, T.A. and Tourangeau, R. (2017), "Contemporary guidance for stated preference studies", Journal of the Association of Environmental and Resource Economists, Vol. 4 No. 2, pp. 319-405.

Karam, B. (2016), Estimation de la valeur économique et sociale des services rendus par les écosystèmes forestiers méditerranéens, Biosphère de Jabal Moussa, Liban, Plan Bleu, Valbonne, available at: http://www.fao.org/3/a-i6117f.pdf.

Larrieu, L. and Gonin, P. (2016), "Présentation de l'Indice de biodiversité potentielle (IBP). CNPF-IDF, INRA Dynafor", available at: https://www.foretpriveefrancaise.com/n/ibp-indice-de-biodiversitepotentielle/n:782.

Mavsar, R., Herreros, F., Varela, E. and Duclerq, M. (2014), "Methods and tools for socio-economic assessment of goods and services by Mediterranean forests in a context of global changes", Plan Bleu, available at: http://planbleu.org/sites/default/files/publications/eval_biens_services_ foret_ffem_c2_en.pdf.

Palahi, M., Mavsar, R., Gracia, C. and Birot, Y. (2008), "In Mediterranean forests under focus", International Forestry Review, Vol. 10 No. 4, pp. 676-688.

Pascual, U., Muradian, R., Brander, L., Gómez-Baggethun, E., Martín-López, B., Verma, M., Farley, J., Loomis, J., Pearson, L., Perrings, C. and Polasky, S. (2010), "The economics of valuing ecosystem services", in Simposon, R.D. (Ed.), The Economics of Ecosystems and Biodiversity (TEEB): Ecological and Economic Foundations, pp. 5-67.

Rabotyagov, S.S. and Lin, S. (2013), "Small forest landowner preferences for working forest conservation contract attributes: a case of Washington state, USA", Journal of Forest Economics, Vol. 19 No. 3, pp. 307-330.

Sarkissian, A.J., Brook, R.M., Talhouk, S.N. and Hockiey, N. (2017), "Asset-building payments for ecosystem services: assessing landowner perceptions of reforestation incentives in Lebanon", Forest Systems, Vol. 26 No. 2, p. 1.

Sattout, E.J., Talhouk, S.N. and Caligari, P.D.S. (2007), "Economic value of cedar relics in Lebanon: an application of contingent valuation method for conservation", Ecological Economics, Vol. 61 No. 2, pp. 315-322.

Sharaunga, S., Mudhara, M. and Wale, E.Z. (2015), "Factors influencing forest value orientations among rural households in KwaZulu-Natal, South Africa", Agroforestry Systems, Vol. 89 No. 6 , pp. 943-962.

Talhouk, S.N., Zurayk, R. and Khuri, S. (2001), "Conservation of the coniferous forests of Lebanon: past, present and future prospects", Oryx, Vol. 35 No. 3, pp. 206-215.

Vatn, A. and Bromley, D.W. (1994), "Choices without prices without apologies", Journal of Environmental Economics and Management, Vol. 26 No. 2, pp. 129-148.

Venkatachalam, L. (2003), "The contingent valuation method: a review", Environmental Impact Assessment Review, Vol. 24, pp. 89-124.

Xiong, K., Kong, F., Zhang, N., Lei, N. and Sun, C. (2018), "Analysis of the factors influencing willingness to pay and payout level for ecological environment improvement of the ganjiang river basin”, Sustainability, Vol. 10, p. 2149.

Zheng, H. and Tu, Q. (2009), "Analysis on willingness to pay for environmental services and its impacts in Jinhua river", Published in International Conference on Managed Science and Engineering.

\section{Further reading}

Mooney, H., Cooper, A. and Reid, W. (2005), "Confronting the human dilemma: how can ecosystems provide sustainable services to benefit society?”, Nature, Vol. 434, pp. 561-562. 


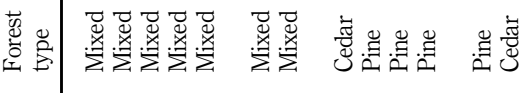


FER

2,1

110

Figure A1.

The socioeconomic survey in the villages around the selected reforested sites

\section{Appendix 2}

Socio- economic survey in the villages around the selected reforested sites

\begin{tabular}{|ll|}
\hline Sheet \#: & Date: \\
Caza: & Village: \\
& \\
\hline
\end{tabular}

\section{Objectives:}

Objective: Reforestation activities were undertaken in selected areas. The purpose of the survey is to:

- Assess the goods and services provided by these reforested sites

- Understand the socio-economic value of these sites

- Highlight the people's willingness to pay for the conservation these sites and increase their areas

The selected sites are found in different areas including in the Cazas of Rachaya, West Beqaa, Zahle, Aley, Shouf and Baabda. 
Section 1: Goods and Services in the selected Reforested Site

1. Can you list some species present in the forest?

2. Do you frequently visit the forest?

$$
\text { Yes }
$$

3. Do you know what types of activities are mostly undertaken in the forest?

$\square$ Grazing

$\square$ Tree pruning for wood/charcoal products or pine nuts products

$\square$ Beekeeping

$\square$ Hunting

$\square$ Aromatic/medicinal plant collection

$\square$ Ecotourism

$\square$ Other services:

4. Do you practice any of these activities?

$$
\begin{aligned}
& \text { 6. If yes, do you practice the activity: } \\
& \square \text { As your main occupation } \\
& \square \text { Secondary occupaton }
\end{aligned}
$$

7. Are recreation/tourism (eco-tourism) activities more frequent for:

$\square$ Local people

$\square$ Lebanese tourists from other regions

$\square$ Foreign tourists

All of the above

\section{Section 2: Valuation Scenario}

8. Which of the following options do you prefer?
Activity
Option 1
Option 2

Options

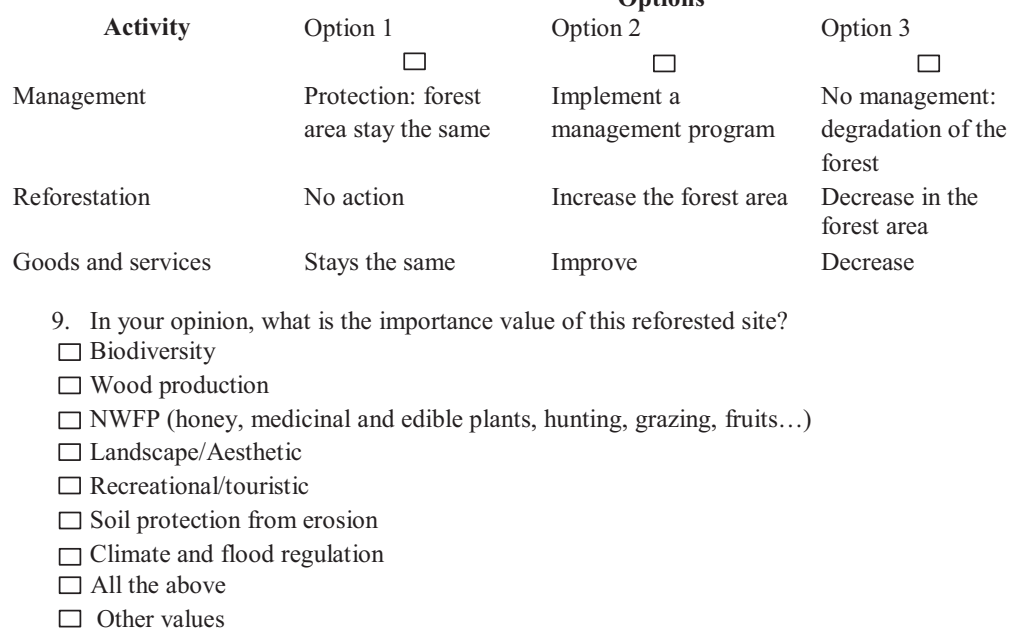

Reforestation for environmental services 
FER

2,1

112

10. What are the risks that the forest may face or is facing? Can you list some?

11. In comparison to the period before the reforestation occurred, do you consider that now the site has:

$\square$ Lost its economic value

$\square$ Lost its environmental value

12. Does the forested site generate employment to anyone?
$\square$ Yes
$\square \quad$ No

14. In your opinion, what would be the cost of losing the forest?

$\square$ Cost in lives and species (biodiversity loss)

$\square$ Degradation of the enviornment (soil, water, air)

$\square$ Degradation of the landscape

$\square$ Reduction of services such as wood NWFP (recreation, spiritual/cultural well-being)

$\square$ All of the above

\section{Section 3: Willingness to Pay (WTP)}

15. The government in collaboration with local and international organizations intends to assist the community in the management of the reforestation site to reduce the risks, reverse degradation, improve the landscape and the production of goods and services and expand the site through reforestation.

If a contribution to implement this project was demanded, will you be willing to pay?

$$
\square \quad \text { Yes } \quad \square \quad \text { No }
$$

If yes, would you be willing to pay the amount of $30,000 \mathrm{LBP}$ per year?

$$
\square \quad \text { Yes } \square \quad \text { No }
$$

If yes, then would you be willing to pay more If no, then would you be willing to pay less than 30,000LBP?

\section{$\square \quad$ Yes \\ No}

If yes, then would you be willing to pay more than the amount of $60,000 \mathrm{LBP}$ ?

$\square \quad$ Yes No than $30,000 \mathrm{LBP}$ ?

Figure A1. 
Section 4: Understanding and Certainty

16. What is the reason of zero WTP?

Reforestation

$\square$ Individual economic situation

for

$\square$ Responsibility of the state

environmental

$\square$ Indifference to existence of the forest

services

$\square$ Occasional user

$\square$ Lack of transparency of the implementing parties (government, municipality, etc.)

$\square$ Other reasons:

17. What is the reason for expressing a WTP for the implementation of the proposed project?

$\square$ Consumptive uses such as wood NWFP and medicinal and aromatic plants

$\square$ Non-consumptive uses such as recreation, spiritual/cultural well-being

$\square$ Conservation for future generations

$\square$ Right of forests to exist

$\square$ All of the above

\section{Section 5: Personal Information}

18. Age

$20-30$

19. Gender: $\square \quad$ Male $\square \quad$ Female

$40-60$

$>60$

20. Education Level:

$\square$ Primary School

$\square$ Secondary School

$\square$ University Studies

21. Main occupation:

Other Occupations:

22. Permanent resident

Summer resident

23. Income

$\square<1,000,000 \mathrm{LBP}$

$\square 1,000,000-2,000,000 \mathrm{LBP}$

$\square 2,000,000-3,000,000 \mathrm{LBP}$

3,000,000-4,000,000LBP

Figure A1.

$\square>4,000,000 \mathrm{LBP}$ 
FER

2,1

\begin{tabular}{|c|c|c|c|c|}
\hline & Variable & Categories & Frequencies & $\%$ \\
\hline & Age & $20-40$ years & 106 & 41.9 \\
\hline \multirow{10}{*}{114} & & $40-60$ years & 104 & 41.1 \\
\hline & & $>60$ years & 43 & 17.0 \\
\hline & Gender & Female & 85 & 33.6 \\
\hline & & Male & 168 & 66.4 \\
\hline & Education level & Primary or secondary school & 159 & 62.8 \\
\hline & & Technical school & 25 & 9.9 \\
\hline & & University studies & 69 & 27.3 \\
\hline & Income (in million Lebanese pounds) & $1-2 \mathrm{~m}$ & 70 & 27.7 \\
\hline & & $2-3 \mathrm{~m}$ & 17 & 6.7 \\
\hline & & $3-4 \mathrm{~m}$ & 9 & 3.6 \\
\hline Table A2. & & $<1 \mathrm{~m}$ & 143 & 56.5 \\
\hline Summary of & & $>4 \mathrm{~m}$ & 8 & 3.2 \\
\hline descriptive data & & NA & 6 & 2.4 \\
\hline
\end{tabular}


Biplot (axes F1 and F2: $100.00 \%$ ) environmental services

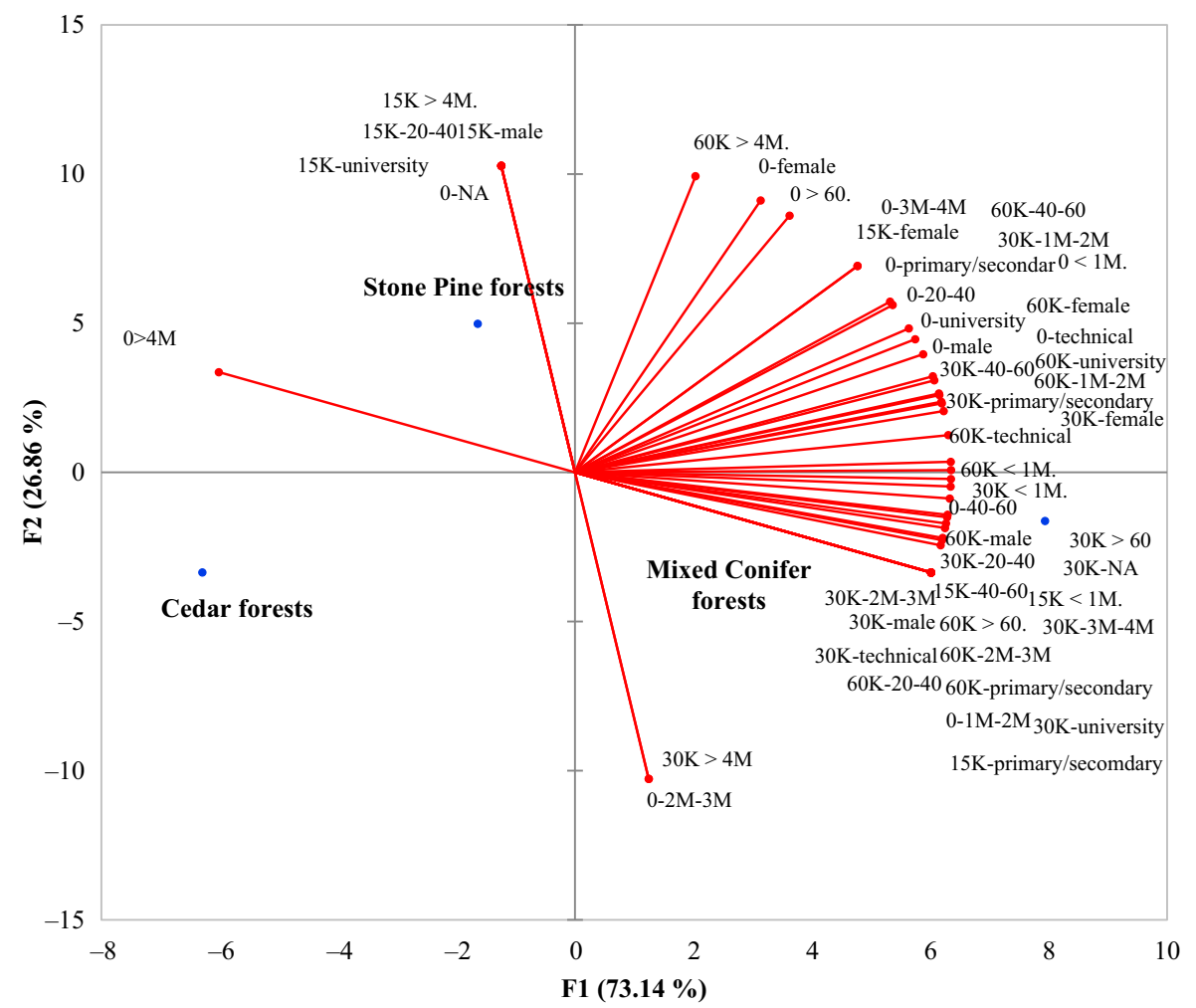

Figure A2.

Socioeconomic factors affecting the willingness to pay $(0$ : no WTP, 30K: 30,000LBP, 15K: 15,000LBP, 60K: 60,000LBP) linked with the three forest types (blue dots) and four socioeconomic factors (age classes, gender, education level and income ranges)

\section{Corresponding author}

Jean Mikhael Stephan can be contacted at: dr.jeanstephan@gmail.com

For instructions on how to order reprints of this article, please visit our website:

www.emeraldgrouppublishing.com/licensing/reprints.htm

Or contact us for further details: permissions@emeraldinsight.com 